\title{
Pelatihan Pembuatan Instan Daun Pepaya sebagai ASI Booster
}

\author{
Krisdiana Wijayanti, Murti Ani, Novita Ika Wardani, Aulia Fatmayanti \\ Email: wijayanti.k@hotmail.com \\ Prodi DIII Kebidanan Blora, Poltekkes Kemenkes Semarang, Indonesia \\ Jl Ahmad Yani PO BOX 2 Blora \\ Telp/Fax: (0296) 5298761
}

\begin{abstract}
Abstrak
Cakupan pemberian ASI ekslusif belum memenuhi target yang telah ditetapkan. Manfaat daun pepaya salah satunya adalah sebagai ASI Booster (pelancar ASI), karena dapat meningkatkan produksi ASI dan kadar protein. Tujuan dari kegiatan pengabmas ini adalah meningkatkan pengetahuan dan ketrampilan tentang ASI dan teknik pembuatan instan daun papaya. Desain nya yaitu pre test dan post test tingkat pengetahuan dan ketrampilan. Materi disampaikan dengan metode ceramah dan demonstrasi. Evaluasi dilaksanakan setelah praktik pembuatan instan daun papaya dengan melakukan post test dan evaluasi pembentukan banner tentang gambaran produk instan daun pepaya dan manfaatnya sebagai pelancar ASI dan adanya forum pertemuan yang ada di desa untuk mengecek deseminasi informasi.Kegiatan pengabmas dilakukan dalam 3 kali pertemuan. Pertemuan pertama yaitu penyampaian materi tentang ASI, pelancar ASI, manfaat daun papaya, teknik pembuatan instan daun papaya. Pertemuan kedua yaitu latihan pembuatan instan daun papaya di Jurusan Gizi Poltekkes Kemenkes Semarang yang diikuti oleh 3 kader Desa Karangjati. Pertemuan ketiga yaitu dilakukan sosialisasi dan praktik pembuatan instan daun papaya di Desa Karangjati kepada masyarakat desa Karangjati. Peserta yang mengikuti kegiatan pengabdian masyarakat ini sejumlah 30 warga Desa Karangjati, Blora. Berdasararkan uji paired ttest didapatkan hasil nilai Sig. (2-tailed) pengetahuan sebesar 0,000 $(<0,05)$ dan ketrampilan sebesar $0,000(<0,05)$, maka terdapat pengaruh pelatihan pembuatan instan daun papaya sebagai ASI booster terhadap tingkat pengetahuan dan ketrampilan. Pengabdian masyarakat ini banyak memberikan manfaat bagi peserta yaitu bagi kader dan warga masyarakat. Bentuk nyatanya adalah meningkatnya pengetahuan tentang ASI dan pelancar ASI dengan pembuatan instan daun pepaya
\end{abstract}

Kata Kunci: pelatihan; instan daun pepaya; ASI booster.

\begin{abstract}
The scope of exclusive breastfeeding has not met the set targets. One of the benefits of papaya leaves is ASI Booster (ASI booster), because it can increase milk production and protein levels. The purpose of this community service activity is to improve knowledge and skills about ASI and the technique of instant papaya leaves. The design is the pre test and post test level of knowledge and skills. The material is delivered by lecture and demonstration methods. The evaluation was carried out after the practice of instant making of papaya leaves by carrying out a post test and evaluating the establishment of a banner on the description of instant papaya leaf products and their benefits as ASI smoothers and meeting forums in the village to check information desemination. Community service activities were conducted in 3 meetings. The first meeting was the delivery of material about ASI, ASI smoothing, the benefits of papaya leaves, the technique of instant papaya leaves. The second meeting was the training of instant papaya leaves in the Semarang Department of Health's Health Polytechnic Department, which was attended by 3 cadres of Karangjati Village. The third meeting was carried out to socialize and practice the instant making of papaya leaves in Karangjati Village to the people of Karangjati village. The participants who participated in the community service activities were 30 residents of Karangjati Village, Blora Based on the paired t-test, the Sig. (2-tailed) knowledge of 0,000 $(<0,05)$ and skills
\end{abstract}


of $0,000(<0,05)$, then there is the effect of training on instant making of papaya leaves as breast milk booster to the level of knowledge and skills. This community service provides many benefits for participants, namely for cadres and community members. The real form is the increasing knowledge of breast milk and ASI smoothers with the instant making of papaya leaves.

Keywords: training; instant papaya leaves; ASI booster.

\section{Pendahuluan}

Kualitas Sumber daya manusia suatu bangsa sangat menentukan jalannya pencapaian pembangunan nasional. SDM yang berkualitas akan didapatkan apabila dilakukan upaya sedini mungkin. Salah satunya adalah dengan pemberian ASI kepada bayi. Hal ini dikarenakan manfaat ASI yang dapat menjamin kesehatan dan kecerdasan anak yang lebih baik. ${ }^{1}$

Banyak bukti bahwa menyusui eksklusif tidak hanya memberikan manfaat untuk bayi, akan tetapi juga memberikan keuntungan kepada ibu. Bayi yang mendapatkan ASI secara eksklusif akan terlindungi dari infeksi pernafasan, diare, asma dan alergi. Risiko kematian bayi secara mendadak (Sudden infant death syndrome) juga dikatakan menurun pada bayi dengan ASI eksklusif (Naughabi Z.S, dkk (2014).Evaluasi yang dilakukan oleh UNICEF Indonesia sendiri termasuk dalam $80 \%$ negara dengan kategori pemberian ASI eksklusif yang rendah yaitu $36 \%$. Terbukti dari Riskesdas 2010 hanya 15,3 bayi yang menyusui eksklusif sampai dengan 6 bulan. Sedangkan dari Riskesdas 2013 masih ditemukan tren yang menurun pada pola pemberian ASI saja dalam 24 jam terakhir. Prosentase terendah pada anak umur 6 bulan yaitu $30,2 \%$. Suatu kondisi yang masih memprihatinkan apabila dilihat dari potensi ASI dalam medukung kualitas hidup anak kedepannya.

Beberapa jenis bahan makanan yang berasal dari tumbuhan telah terbukti dapat meningkatkan produksi ASI (lactogogue).Daun katu terbukti meningkatkan $50,7 \%$ produksi ASI (Sa'roni, 2004). Daun lembayung juga ditemukan dapat meningkatkan produksi ASI karena mengandung saponin dan polifenol yang bisa meningkatkan hormon prolaktin ibu menyusui.

Makanan atau sayuran yang bisa mempelancar produksi ASI sangat banyak diperkenalkan oleh orang tua secara turun temurun, diantaranya adalah pepaya hijau atau mentah, bunga pepaya, daun pepaya, daun jinten, biji nangka, sukundan asparagus.Tanaman pepaya dapat dimanfaatkan pada setiap bagiannya, baik buah, bunga maupun daunnya. Mendapatkan tanaman pepaya di daerah tropis seperti Indonesia khususnya Kabupaten Blora juga lebih mudah dibanding dengan mendapatkan jenis bahan makanan lain yang diduga dapat memperlancar produksi ASI. Menurut data yang didapatkan, pada tahun 2014 di Blora, terdapat 21.197 batang pohon pepaya yaitu tanaman buah terbanyak ketiga setelah mangga dan pisang. Meningkat jumlahnya dibandingkan tahun 2012 dan 2013 yaitu 15.737 dan 17.103 batang pohon. ${ }^{2}$

Manfaat daun pepaya menurut beberapa hasil penelitian adalah sebagai penurun demam, 
penambah nafsu makan, obat luka, dan sebagai pengobatan pada tumor dan kanker. Sementara itu, berdasarkan penelitian terkini oleh Wijayanti,K (2016) ditemukan bahwa ada perbedaan kenaikan berat badan bayi pada ibu yang diberi ekstrak daun pepaya dengan yang tidak diberi ekstrak daun pepaya, pada nilai mean didapatkan hasil berat badan bayi ibu yang diberi ekstrak daun pepaya lebih tinggi dibanding berat badan bayi dari ibu yang tidak diberi ekstrak daun pepaya. Hal ini membuktikan bahwa pengetahuan empiris tentang daun pepaya yang selama ini digunakan oleh masyarakat ternyata juga bermanfaat sebagai ASI Booster (pelancar ASI), karena dapat meningkatkan produksi ASI dan kadar protein. Untuk itu diperlukan diseminasi hasil penelitian tersebut ke dalam pengabdian kepada masyarakat dalam bentuk pelatihan pembuatan instan daun pepaya.

Desa Karangjati sebagai salah satu desa yang terletak di Kabupaten Blora juga berperan dalam mendukung upaya menyusui dan memberikan ASI Eksklusif. Hal ini mendorong Prodi DIII Kebidanan Blora Poltekkes Kemenkes Semarang yang memiliki visi utama di bidang laktasi, untuk melaksanakan kegiatan Pengabdian kepada Masyarakat (Pengabmas) berupa pelatihan pembuatan instan daun pepaya sebagai ASI Booster pada masyarakat Desa Karangjati, Kabupaten Blora sebagai bentuk dukungan terhadap program pemerintah di bidang kesehatan dan perwujudan Tri Dharma Perguruan Tinggi. Tujuan dalam kegiatan pengabmas ini adalah meningkatkan pengetahuan masyarakat tentangmanfaat daun papaya untuk ASI dan keterampilan pembuatan instan daun papaya.

\section{Metode}

Kegiatan pengabdian masyarakat yang dimulai dengan pembuatan materi tentang ASI, pelancar ASI, manfaat daun papaya, teknik pembuatan instan daun papaya. Kemudian dilakukan latihan pembuatan instan daun papaya di Jurusan Gizi Poltekkes Kemenkes Semarang yang diikuti oleh 3 kader Desa Karangjati, Blora. Tahap berikutnya yaitu dilakukan sosialisasi dan praktik pembuatan instan daun papaya di Desa Karangjati kepada masyarakat desa Karangjati dan ditunjukkan dengan banner tentang gambaran produk instan daun pepaya dan manfaatnya sebagai pelancar ASI dan adanya forum pertemuan yang ada di desa untuk mengecek deseminasi informasi. Peserta yang mengikuti kegiatan pengabdian masyarakat ini sejumlah 30 warga Desa Karangjati, Blora.

Kegiatan Pengabmas ini akan dilaksanakan sebanyak $3 \quad x$ pertemuan pada tanggal 1 dan 3 Agustus dan 13 September 2018. Intervensi yang dilakukan dalam kegiatan ini yaitu pemberian materi menggunakan power point dan juga video tentang pengertian ASI dan ASI Eksklusif, pemberian materi tentang manfaat daun pepaya dan teknik pembuatan instan daun pepaya sebagai pelancar ASI, latihan dan pendampingan pembuatan instan daun pepaya sebagai pelancar ASI, peserta mempraktikkan pembuatan instan daun pepaya di desa.

Evaluasi dalam kegiatan ini meliputi evaluasi pengetahuan 
tentang ASI dan instan daun pepaya berbentuk pre dan post test. Untuk ketrampilan pembuatan instan daun pepaya dievaluasi dengan dihasilkannya produk instan daun pepaya yang dibuat sesuai dengan petunjuk yang ditetapkan. Pengabdi melakukan evaluasi terhadap kegiatan sosialisasi yang dilakukan peserta terlatih kepada masyarakat tentang manfaat daun pepaya dan pembuatan instan daun pepaya sebagai Pelancar ASI, dan ditunjukkan dengan banner tentang gambaran produk instan daun pepaya dan manfaatnya sebagai pelancar ASI dan adanya forum pertemuan yang ada di desa untuk mengecek deseminasi informasi.

Penilaian keberhasilan dalam kegiatan ini dilakukan secara sistematis. Tolak ukur keberhasilan kegiatan ini adalah diperolehnya pengetahuan subjek terhadap ASI, manfaat daun pepaya, teknik pembuatan instan daun pepaya dan adanya respon positif dari peserta untuk melakukan pengenalan terhadap masyarakat luas tentang manfaat dan teknik pembuatan instan daun pepaya. Evaluasi juga dilakukan pada forum pertemuan yang ada di desa untuk mengecek deseminasi informasi. Evaluasi keseluruhan kegiatan tersusun dalam Laporan Hasil Pengabdian Masyarakat dengan memperhatikan dan mempertimbangkan kritik, saran dan masukan dari pihak-pihak terkait.

\section{Hasil dan Pembahasan}

a. Karakteristik peserta kegiatan

Tabel 1. Karakteristik peserta berdasarkan tingkat pendidikan

\begin{tabular}{llll}
\hline Karakteristik & & $\mathrm{f}$ & \multicolumn{1}{c}{$\%$} \\
\hline $\begin{array}{l}\text { Tingkat } \\
\text { Pendidikan }\end{array}$ & SMP & 4 & 13,3 \\
& & & 3 \\
& SMA & 2 & 80 \\
& DIII & 2 & 6,67 \\
Pekerjaan & IRT & 2 & 93,3 \\
& & 8 & 3 \\
& Pegawai & 2 & 6,67 \\
& swasta & & \\
Umur & $20-35$ & 5 & 16,6 \\
& tahun & & 7 \\
& $>35$ & 2 & 80 \\
& tahun & 4 & \\
\hline
\end{tabular}

Sumber: Data primer (2018)

Berdasarkan tabel1 diketahui bahwa sebagian besar tingkat pendidikan peserta adalah SMA yaitu sebanyak 24 orang (80 \%).Pekerjaan sebagian besar peserta adalah sebagai IRT yaitu sebanyak 28 orang $(93,33 \%)$.Usia sebagian besar peserta adalah $>35$ tahun yaitu sebanyak 24 orang ( 80 $\%)$.

b. Nilai rata-rata tingkat pengetahuan dan ketrampilan peserta sebelum dan sesudah Tabel 2. Skor Rata-Rata

\begin{tabular}{ccl}
\hline Mean & Sebelum & Sesudah \\
\hline Pengetahuan & 48,43 & 73,97 \\
Keterampilan & 50,77 & 85,90 \\
\hline
\end{tabular}

Sumber: Data primer (2018)

Berdasarkan tabel 2 diketahui bahwa skor rata-rata tingkat pengetahuan peserta sebelum diberikan pelatihan adalah 48,43 
dan setelah diberikan pelatihan rata-rata 73,97. Skor rata-rata ketrampilan peserta sebelum diberikan pelatihan adalah 50,77 dan setelah diberikan pelatihan rata-rata 85,90 .

c. Uji Paired T-Test Tingkat Pengetahuan dan Ketrampilan

Sebelum dilakukan uji paired t-test, dilakukan uji normalitas data menggunakan Shapiro wilk. Hasil uji normalitas data menggunakan Shapiro Wilk skor pretest pengetahuan adalah $0,065(>0,05)$ dan skor posttest pengetahuan adalah $0,180(>0,05)$ yang berarti data berdistribusi normal.Hasil uji normalitas data menggunakan Shapiro Wilk skor pretest ketrampilan adalah $0,236(>0,05)$ dan skor posttest ketrampilan adalah $0,092(>0,05)$ yang berarti data berdistribusi normal.

Tabel 3 Uji Paired T-Tes Tingkat Pengetahuan dan Ketrampilan

\begin{tabular}{clcc}
\hline Variabel & Mean & SD & $\begin{array}{c}\text { P } \\
\text { value }\end{array}$ \\
\hline Pengetahuan & - & 19.006 & 0.000 \\
& 25.533 & & \\
Keterampilan & - & 14.340 & 0.000 \\
& 35.133 & & \\
\hline
\end{tabular}

Sumber: Data primer (2018)

Berdasarkan tabel 3 pengetahuan $\mathrm{P}$ sebesar $0,000<$ 0,05 maka terdapat perbedaan yang signifikan antara tingkat pengetahuan pada data pretest dan posttest yang artinya terdapat pengaruh pelatihan pembuatan instan daun papaya sebagai ASI Booster terhadap tingkat pengetahuan. Keterampilan $p$ sebesar $0,000<0,05$ maka terdapat perbedaan yang signifikan antara ketrampilan pada data pretest dan posttest yang artinya terdapat pengaruh pelatihan pembuatan instan daun papaya sebagai ASI Booster terhadap ketrampilan.

Pendidikan

kesehatan

merupakan upaya untuk mempengaruhi dan mengajak orang lain baik individu, kelompok, atau masyarakat agar melaksanakan perilaku hidup sehat. Diharapkan melalui pendidikan kesehatan dapat mengubah perilaku masyarakat dari perilaku yang negatif mengarah ke perilaku yang positif. Untuk mencapai perilaku positif terdapat beberapa faktor yang mempengaruhi proses perubahan tersebut, yaitu predisposing factors, enabling factors, dan reinforcing factors. Selain itu proses perubahan perilaku juga didahului oleh perubahan pengetahuan, perubahan sikap atau persuasi, pengambilan keputusan, sehingga pada akhirnya akan tercapai tahap implementasi dan konfirmasi. $^{3}$

Dari hasil analisis data tentang kegiatan pengabmas didapatkan bahwa pengetahuan ibu mengalami peningkatan setelah mendapatkan pelatihan menggunakan metode ceramah dan demonstrasi. Hal tersebut menunjukkan adanya pengaruh yang signifikan berupa peningkatan pengetahuan dan ketrampilan ibu tentang manfaat daun papaya sebagai ASI Booster dan cara membuat instan daun pepaya.

Pelatihan perlu didesain secara efektif untuk memastikan bahwa program pelatihan telah mencapai efisiensi yang optimal serta mencapai keuntungan belajar yang maksimal. Ketrampilan adalah kemampuan melaksanakan tugas atau pekerjaan dengan menggunakan anggota badan dan 
peralatan kerja yang tersedia. kemampuan dasar mempunyai 3 komponen, salah satunya yaitu kemampuan untuk menggunakan alat, prosedur dan teknik yang berhubungan dengan bidangnya. ${ }^{4}$

Pengetahuan peserta sebagian besar menjadi pengetahuan baik. Hal ini sejalan dengan penelitian Hidayati, Salawati dan Istiana (2015) yang menyatakan bahwa metode demonstrasi lebih mudah untuk menunjukkan pengertian, ide, dan prosedur tentang suatu hal yang pernah dipersiapkan dengan teliti untuk memperlihatkan bagaimana cara melaksanakan suatu tindakan adegan dengan menggunakan alat peraga. Informasi yang diperoleh dari petugas kesehatan dapat memberikan pengaruh jangka pendek sehingga menghasilkan perubahan atau peningkatan pengetahuan serta keterampilan ibu.

Berdasarkan penelitian Dewi dan Kurniawan tahun 2016 bahwa pelatihan dapat mempengaruhi pengetahuan dan keterampilan seseorang tentang pembuatan instan daun papaya setelah diberikan materi. Penelitian ini didukung oleh oleh Septiani, Budi, Karbito (2017) keterampilan diperoleh dari hasil mendengarkan dan mempertimbangkan informasi yang telah didapat sehingga mampu untuk melakukan tindakan yang positif sesuai dengan yang diinginkan. Sehingga sikap positif tentang instan daun papaya akan berpengaruh pada peningkatan produksi ASI. ${ }^{5}$

Untuk meningkatkan kesehatan keluarga, upaya yang dapat dilakukan para ibu dalam keluarga adalah dengan mencegah kejadian sakit. Oleh karena itu, dalam pelatihan ini ibu-ibu diajarkan praktek membuat instan daun pepaya yang aman dikonsumsi sehari-hari yang berkhasiat sebagai pelancar ASI. Inilah pentingnya peran ibu dalam keluarga untuk memelihara kesehatan keluarga, sehingga melalui kegiatan ini, jika para ibu mempraktekkan dalam keluarganya diharapkan kejadian sakit dalam keluarga menjadi menurun. ${ }^{6}$

Instan daun pepaya dapat mempengaruhi dalam peningkatan produksi ASI karena memiliki sifat lagtogogum dan mengandung zat mineral Mangan (Mn). Mangan (Mn) adalah zat yang penting dalam fungsi glandula pituitary. ${ }^{7}$ Penelitian Turlina dan rindy (2015) menunjukkan bahwa sering mengkonsumsi daun pepaya pada waktu nifas dapat meningkatkan produksi ASI. Dimana ASI akan meningkat pada hari ke-2 setelah mengkonsumsi daun papaya. ${ }^{8}$

Menurut penelitian Abel dan Busia (2005), Sekitar 75 persen populasi di Ghana bergantung pada obat tradisional untuk perawatan kesehatan primer. Masyarakat masih tergantung dalam obat tradisional. Pengetahuan tradisional tentang penyembuhan dan penggunaan tanaman obat disebarkan dari generasi ke generasi oleh anggota keluarga. Namun, perolehan kualifikasi akademik sekarang menjadi prioritas, dan pelatihan formal sedang berlangsung. Obat tradisional dibuat lebih praktis, menarik dan hygienis. Instan daun pepaya merupakan produk yang sudah dibuat lebih praktis dengan tinggal menyedu dengan air hangat saja. ${ }^{9}$ 


\section{Kesimpulan}

Kegiatan pelatihan berjalan dengan baik dan mendapat dukungan dari berbagi pihak.Dilakukannya demonstrasi dan praktik pembuatan instan daun papaya sebagai ASI booster selama pelatihan dapat meningkatkan pemahaman peserta.

Pengabdian masyarakat ini banyak memberi manfaat bagi peserta, bentuk nyatanya adalah peningkatan pengetahuan dan ketrampilanSkor rata-rata tingkat pengetahuan peserta sebelum diberikan pelatihan adalah 48,43 dan setelah diberikan pelatihan rata-rata 73,97. Skor rata-rata ketrampilan peserta sebelum diberikan pelatihan adalah 50,77 dan setelah diberikan pelatihan rata-rata 85,90. Nilai Sig. (2-tailed) uji paired t test sebesar $0,000(<$ $0,05)$ maka terdapat pengaruh pelatihan pembuatan instan daun papaya sebagai ASI booster terhadap tingkat pengetahuan. Nilai Sig. (2-tailed) uji paired t test sebesar $0,000 \quad(<0,05)$ maka terdapat pengaruh pelatihan pembuatan instan daun pepaya sebagai ASI booster terhadap ketrampilan pembuatan instan daun papaya.

Peserta yang sudah mendapatkan pelatihan diharapkan dapat mengaplikasikan ilmu yang diterima dengan melakukan praktik pembuatan instan daun papaya. Peserta melakukan transfer of knowledge (transfer ilmu pengetahuan) terhadap lingkungan sekitar tentang pembuatan instan daun sehingga ibu menyusui dapat meningkatkan produksi ASI

\section{Daftar Pustaka}

[1] Kementerian Kesehatan RI. Profil Kesehatan Indonesia Tahun 2012. Jakarta, 2013.

[2] Bappeda Blora. Profil Kesehatan Kabupaten Blora 2015. Jawa Tengah. 2015.

[3] Notoatmodjo, S. Promosi kesehatan dan Perilaku Kesehatan. Jakarta: Rineka cipta. 2012.

[4] Laraeni, Y., \& Wiratni, A. Pengaruh Penyegaran Kader Terhadap Pengetahuan dan Keterampilan Kader Posyandu Menggunakan Dacin di Wilayah Kerja Puskesmas Dasan Cermen Kecamatan Sandubaya Kota Mataram. Jurnal Media Bina Insani. ISSN, (1978-3787). 2014.

[5] Dewi, F. K., \& Kurniawan, W. E. Pengaruh Pelatihan Tentang Mpasi Homemade No Gulgar Terhadap Pengetahuan Dan Ketrampilan Ibu Nifas. Jurnal Kesehatan Al-Irsyad, pp.6169. 2016.

[6] Maryani, M., \& Rosdiana, R. Upaya Swamedikasi dengan Tanaman Obat pada Kelompok Ibu-ibu Pkk di Kelurahan Kalampangan. PengabdianMu: Jurnal Ilmiah Pengabdian Kepada Masyarakat, 3 (1), pp.27-33. 2018.

[7] Ayoola, P. B., \& Adeyeye, A. Phytochemical and nutrient evaluation of Carica papaya (pawpaw) leaves. IJRRAS, 5(3), pp.325-328. 2010. 
[8] Turlina dan rindy. Pengaruh Pemberian Serbuk Daun Pepaya Terhadap Kelancaran Asi Pada Ibu Nifas Di Bpm Ny. Hanik Dasiyem, Amd.Keb Di Kedungpring Kabupaten Lamongan. Lamongan: STIKES Muhammadiyah Lamongan. 2015.

[9] Abel, C., \& Busia, K. An exploratory ethnobotanical study of the practice of herbal medicine by the Akan peoples of Ghana. Alternative Medicine Review, 10(2). 2005. 